\title{
ZNAČAJ INVESTICIJA U OBRAZOVANJE ZA EKONOMSKI RAZVOJ NR KINE
}

\author{
THE IMPORTANCE OF INVESTMENTS IN EDUCATION FOR \\ ECONOMIC DEVELOPMENT OF P.R. CHINA
}

\section{Katarina Peters}

Fakultet poslovna ekonomija, Univerzitet Singidunum, Beograd, Srbija

\section{Marko Blažević}

Fakultet za engleski jezik, Univerzitet stranih studija u Hebeju, Šiđadžuang, NR Kina

\section{CMESTE}

JEL kategorija rada: I25, N35, 043, 053, P25

\begin{abstract}
Apstrakt
Ovaj rad se bavi problematikom obrazovanja u Narodnoj Republici Kini i potencijalnim ekonomskim razvojem usled investicija u obrazovni sistem. U periodu od 1998. beleži se nagli skok obrazovanja koji je između ostalog ispraćen pozitivnim rastom domaćeg bruto proizvoda. Krucijalni značaj ulaganja u obrazovanje je obezbeđivanje kompetentne radne snage koja predstavlja stub uspešne moderne ekonomije. Poteškoća pravilne raspodele resursa i reforme obrazovanja predstavlja hukou sistem u Kini, koji ograničava ljude na život $i$ rad u određenoj sredini, odnosno prepreku ka slobodnom kretanju stanovništva i jednakoj šansi za obrazovanje. Do sada je zabeležena diskrepanca između ruralnog $i$ urbanog hukou-a, pri čemu urbani hukou beleži veći procenat obrazovanih, kao i proporcionalno viša primanja, dok ruralni hukou beleži nedostatak mogućnostii za daljim obrazovanjem. Da bi Kina ostvarila planirani ekonomski rast, evidentno je da mora da izvrši reformu obrazovanja, čiji fokus bi bio na unapređenju ljudskog kapitala, kao i da izdvoji veći procenat bruto domaćeg proizvoda za investicije $u$ obrazovanje.
\end{abstract}

Ključne reči: Kina, obrazovanje, ekonomski razvoj, investicije, ljudski kapital

\section{Abstract}

This paper deals with educational issues in the People's Republic of China and potential economic development due to investments in the education system. In the period from 1998, there was a big growth in education which was accompanied, among other things, by positive growth in gross domestic product. The crucial importance of investing in education is providing a competent workforce which is a pillar of a successful modern economy. There is a

The adress of the author:

Katarina Peters

莑nninaketi@hotmail.com difficulty of the proper allocation of resources and the reform of education is the hukou system in China, which restricts people to live and work in a certain location which is an obstacle for people to 
freely move and equal chances for education. So far, the discrepancy between rural and urban hukou has been noticed, with urban hukou recording a higher percentage of educated people, as well as a proportionally higher income, while rural hukou is lacking opportunities for further education. For China to achieve the planned economic growth, it is evident that it must reform its education, the focus of which would be on improving human/knowledge capital as well as set aside a higher percentage of gross domestic product for investments in education.

Keywords: China, education, economic development, investment, human/knowledge capital

\section{UVOD}

Predmet istraživanja ovog rada je značaj obrazovanja u procesu održivog ekonomskog razvoja, a cilj istraživanja je utvrđivanje da je obrazovanje jedan od ključnih preduslova ekonomskog rasta i održivog ekonomskog razvoja Narodne Republike Kine. Tokom pisanja rada korišćene su osnovna i opštenaučna metoda istraživanja. Induktivna metoda je korišćena pri posmatranju i analizi činjenica, a komparativna i statistička za analizu podataka Svetske Banke, Kineskog nacionalnog biroa za statistiku i drugo. (Peters, 2020)

Moderna ekonomija se oslanja na pravilno upravljanje ljudskim resursima, koje je podložno konstantnim promenama a dobro razvijen ljudski kapital obezbeđuje konkurentsku prednost. Promene je neophodno razumeti $\mathrm{i}$ ispratiti, a zatim im prilagoditi pravilan pristup da bi društvo $\mathrm{i}$ ekonomija mogle da funkcionišu. $U$ današnje vreme tehnologija pravi još veću diskrepancu između poslova, za koje su potrebne samo osnovne veštine i između bolje plaćenih poslova, koji zahtevaju visoko obrazovnu radnu snagu, koja nije lako zamenljiva. Da bi ekonomija opstala u procesima globalizacije i turbulentnosti tržišta, a time i poslovanja koje je opterećeno finansijskom i opšteekonomskom krizom, ona mora biti vođena od strane stručnog menadžmenta ( (Stamatović \& Ercegović, 2020). $\mathrm{Da}$ bi se ovi zahtevi ispunili, a radnici bili adekvatno obučeni za buduće poslove, neophodno je dalje prilagođavati obrazovanje traženim normama. Ako se ekonomija zasniva na radu, a rad na kvalitetno obučenim radnicima, države sebi ne smeju dopustiti da školstvo i dalje nosi karakteristike prošlih, zastarelih vremena $i$ da generacijski proizvodi radnike, koji nemaju veštine neophodne za rad. Ulaganje u obrazovanje se odnosi na budućnost, a ulaganje je određeno nizom odluka u prošlosti, sadašnjim i budućim očekivanim resursima, tržištem, politikom i drugim institucijama. Danas bi obrazovanje trebalo biti prioritet svake države, počev od pružanja podrške roditeljima, ne bi li usmerili decu ka daljem obrazovanju, pa do prepoznavanja potreba tržišta i promovisanja obrazovanja kao načina za lakše zaposlenje.

\section{OPŠTE KARAKTERISTIKE KINE}

Narodna Republika Kina je osnovana 1949. godine, ali se tek nakon ekonomskih reformi 1978. godine otvara ka svetu i postaje najveća trgovačka i ekonomska sila a trgovina Kine čini 59\% globalnog BDP-a 2018. godine.

$\mathrm{Na}$ jugu i jugoistočnoj obali Kine, 1978. godine Deng Xiaoping započinje industralizaciju Kine, pretvarajući Shenzhen u metropolu u kojoj sada živi 12,6 miliona ljudi (Marshall, 2015). Prema podacima za 2019. godinu, Shenzhen ostvaruje bruto domaći proizvod (BDP) od \$396,9 milijardi, te se nalazi na trećoj poziciji posle Pekinga i Šangaja (Izvor: Shenzhen Government Online). Kako je prosperitet bio uslovljen trgovinom, unutrašnjost Kine biva zapostavljena, a već tada dolazi do velike migracije naroda koji se seli u velike gradove koji nude poslove i prosperitet, te to još više izoštrava regionalne razlike.

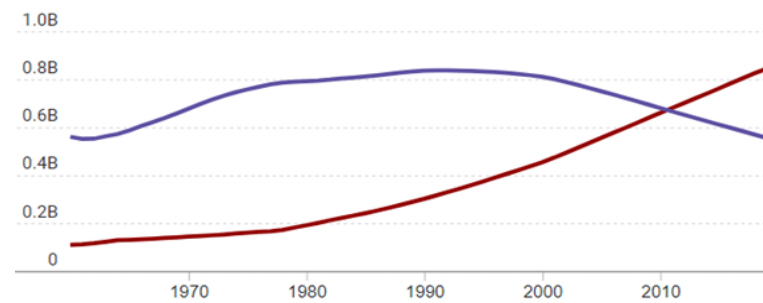

Slika 1. Kretanje populacije u urbanim i ruralnim predelima Kine

Izvor: (Svetska banka, 2020)

Slika 1. pokazuje kretanje populacije u urbanim i ruralnim predelima Kine, odnosno pad populacije $\mathrm{u}$ ruralnim predelima, ali $\mathrm{i}$ rast populacije $\mathrm{u}$ urbanim. Ljubičasta linija kretanja predstavlja ruralnu populaciju, dok crvena linija predstavlja urbanu. 
Međutim, iako Kina započinje svoj rast kao zemlja jeftine radne snage, ona prepoznaje potencijal ekspanzije znanja i veština, te započinje reformisanje obrazovanja sa ciljem da isprati promene u svetu, ali i da obezbedi školovanu radnu snagu na koju može da se osloni. Kina ima zadatak da radi na ljudskom razvoju, kao i na smanjenju nejednakosti. HDI (Human development index) u Kini iznosi 0,758 (UN Development Program, 10.12.2019), što Kinu stavlja na 85. mesto od 189 zemalja ukupno. Međutim, IHDI (Inequality-adjusted human development index) u Kini iznosi svega 0,636.

Gini koeficijent Kine 2018. godine iznosi 0,467 (izvor Svetska banka), a on je uslovljen neravnomernom regionalnom distribucijom dohotka. Istočna obala Kine je pokretač brzog rasta Kine zbog svog geografskog položaja, te ovu oblast naseljava 38\% ukupne populacije, a BDP je $77 \%$ veći nego u ostalim regionima. Shodno tome, većina investicija je usmerena ka urbanom regionu, dok ostatak Kine zaostaje (izvor Svetska banka). Slika 2. pokazuje kretanje Gini koeficijenta od 2009. do 2019. godine.

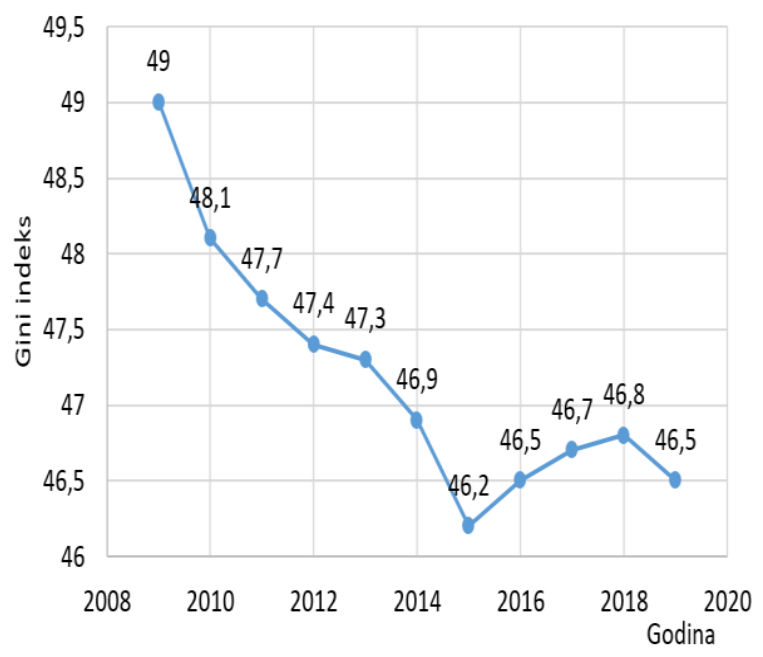

Slika 2. Gini koeficijent Kine u periodu 2009 2019. godine

Izvor: (Svetska banka, 2020)

Kakav odnos ima Kina prema održivom razvoju i tehnološkom napretku pokazuje njihov trinaesti petogodišnji plan (2016 - 2020) koji obuhvata sledeće ciljeve (izvor Centralni komitet Komunističke partije Kine):

- napuštanje teške industrije i izgradnja moderne informacione-intenzivne infrastrukture
- premošćivanje razlika između sela i gradova efikasnijim upravljanjem resursima

- ostvarivanje rezultata u razvoju inovacija

- razvijanje industrije ekološke tehnologije i poboljšanje celokupnog kvaliteta životne sredine i ekosistema

- sprovođenje univerzalne zdravstvene zaštite

Veliki segment ovog petogodišnjeg plana je između ostalog plan Made in China 2025 koji obuhvata nadogradnju kineske industrije i prisvajanje većeg dela globalnog proizvodnog lanca. Projekat Made in China 2025 bi trebao da reši sledeće probleme; povezivanje kineskih industrijskih proizvoda sa lošijim kvalitetom, problem velike domaće konkurencije usled homogene strukture, kao i pitanje bolje upotrebe rezultata akademskih istraživanja.

\section{REFORMA OBRAZOVANJA U KINI}

\subsection{Mračno doba obrazovanja u Kini}

Od osnivanja NR Kine 1949. godine, Kina prolazi kroz mnogobrojne obrazovne reforme. Od perioda osnivanja do Kulturne revolucije 1966. godine, Kina usvaja model Sovjetskog Saveza, te sprovodi reformu obrazovanja, fokusirajući se na jačanje škola koje mogu doprineti razvoju ekonomije, politehnike, medicine, poljoprivrede i politike (Kang, 2004). Obrazovni model se sastojao od šest godina osnovnog i šest godina srednjeg obrazovanja (Guo, 2012). Ova reforma prvobitno donosi veliki uspeh, ali takođe sadrži i nedostatke; fokus samo na pojedine grane obrazovanja i finansiranje isključivo od strane države koja kasnije vrši raspodelu maturanata. Kulturna revolucija 1966. godine menja celokupnu sliku Kine kao države, a obrazovanje gubi svoj pravi značaj (Otafiire, Lin, \& Blažević, 2019).

Kina i njeno formalno obrazovanje ulazi u mračni period, tokom kog je svaki vid školstva zabranjen. Ono biva prepušteno neobrazovanoj i neadekvatnoj nekolicini koja dalje sprovodi reforme. Decenija koja prati početak Kulturne revolucije je ispraćena glađu, nestašicom i lošim životnim uslovima, a beleži se i najveći pad BDP (1967. godine -8,16\%, 1968. godine - 6,5\%). Tek se sa dolaskom Deng Xiaoping-a beleži stabilni godišnji rast; 1978. godine $10,18 \%$ (izvor Svetska banka). 


\subsection{Obrazovne reforme i Deng Xiaoping}

Deng Xiaoping rekonstruiše obrazovni sistem 1977. godine. On prepoznaje obrazovnu reformu kao prvi korak socijalne reforme u Kini i vraća prijemne ispite kao način upisavanja u obrazovne institucije (Kang, 2004). Pored obrazovnih reformi istorijska odluka da se kineski ekonomski sistem okrene sa planske ka tržišnoj ekonomiji je donešena 1980. godine (Feng, 2006).

Dramatična promena ekonomskog sistema inicira konsekventne promene u političkom sistemu, ka decentralizaciji i demokratiji. Brz socijalni, ekonomski i politički razvoj u Kini zahteva fundamentalne promene u obrazovanju. Potrebno je poboljšati obrazovni sistem i njegov kvalitet, kao i obskrbiti narod znanjem i veštinama koje odgovaraju globalizaciji (Hanushek \& Woessmann, 2010).

Celo društvo u Kini se menja 1988. godine, a obrazovanje postaje ključni aspekt socijalne reforme i razvoja. Socijalistička ekonomska konstrukcija stvara veliku i specifičnu potrebu za većim brojem kvalitetnih radnika, te to postaje najvažniji faktor razvoja obrazovanja u Kini (Kang, 2004). Deng Xiaoping objavljuje da će obrazovanje imati tri karakteristike: biće okrenuto ka svetu, modernizaciji i budućnosti.

Investicije u obrazovanje doživljavaju skok od 1998. godine, studenti počinju da plaćaju školovanje 1999. godine, a država obezbeđuje stipendije za određene studente koji nemaju finansijsku mogućnost za isto (Kang, 2004).

Ulazak Kine u Svetsku trgovinsku organizaciju 2001. godine dovodi do potrebe za višim modelom obrazovanja. Ministarstvo prosvete $u$ Kini objavljuje pregled reformi programa osnovnog obrazovanja (Basic education curriculum reform outline) u junu 2001. godine $i$ tada zvanično počinje najbitnija reforma $u$ kineskog modernoj obrazovnoj istoriji: Reforma novog programa (The New Curriculum Reform, NCR).

\section{NEJEDNAKOST OBRAZOVANJA}

PRISTUPU

Egalitarni pristup srednjekvalifikovanom obrazovanju, karakterističan za predreformsku eru, dovodi do značajne nejednakosti u pristupu višim nivoima obrazovanja. Rast i razvoj Kine će podstaći, ali i biti podstaknut ekspanzijom pristupa svim nivoima obrazovanja, smanjenjem prepreka za mobilnost radne snage i širenjem privatnog sektora (Heckman \& Yi, 2012). Visoka štednja, akumulacija fizičkog kapitala i integracija Kine u svetsku ekonomiju tokom 80tih i 90tih godina dovodi do tražnje za visoko kvalifikovanim radnicima. Vlada reaguje na ovu potrebu radikalnom ekspanzijom obrazovanja, što dovodi do porasta veštine radne snage u prvoj deceniji 21. veka (Heckman \& Yi, 2012).

Veliki problem ostaje nejednakost u pristupu obrazovanju, pogotovo dece iz ruralnih predela i dece iz porodica sa ograničenim prihodima, jer je obrazovanje nakon osnovne škole finansira porodica.. Ovi faktori utiču na socijalnu mobilnost i produžuju međugeneracijsko siromaštvo (Heckman \& Yi, 2012). Broj upisanih u osnovne i srednje škole u Kini je 70ih godina bio mnogo veći nego u ostalim Azijskim zemljama (Becker, Ye, \& Yi, 2012). BDP u Kini je 1979. godine iznosio $2 \%$ od BDP-a u Sjedinjenim Američkim Državama, ali politika otvorenih vrata (Open Doors policy) dovodi do priliva fizičkog kapitala od 1979. godine. Strane direktne investicije iznose $\$ 1,096,6$ milijardi u periodu 1979 - 2008. godine.

lako se Kina aktivno razvijala, bio je potreban veliki napor da oporavi visoko obrazovanje, koje je bilo suspendovano od 1966. do 1976. godine, a doživljava rast sa $1,5 \%$ na $2,5 \%$ tek u periodu 1979 - 1995. godine (NBS, 2011). Ekonomski rast i akumulacija fizičkog kapitala utiče na rast prisutnosti obrazovanja. Kina zadržava nivo nacionalne bruto štednje na $35-55 \%$ kroz celokupnu ekonomsku reformu, sa dramatičnim rastom marginalne produktivnosti rada, pogotovo nove tehnologije, koja se snažno dopunjava sa radom koji zahteva visoke kvalifikacije (Liang, Liu, \& Li, 2016).

Potreba za tercijalnim obrazovanjem dovodi do odluke vlade da se 1999. godine implementira ekspanzija visokog obrazovanja. U skladu sa tim, 2001. godine broj maturanata raste sa 960,000 na $6,350,000$ u 2010. godini. Tercijalno obrazovanje raste sa $3 \%$ na $19 \%$ tokom istog perioda (Constant, Tien, Zimmermann, \& Meng, 2013). 


\subsection{Hukou sistem i obrazovanje u Kini}

Problem nejednakosti pristupa obrazovanju u Kini je između ostalog posledica tzv. hukou sistema, koji vezuje ljude za mesto gde su se rodili, odnosno odakle njihova porodica potiče. Osnovan je 1950. godine, kako bi se pratilo kretanje naroda i održao red, dok je Kina bila planska ekonomija. Hukou se nasleđuje od roditelja i ima dve dimenzije; mesto (rezidencija) i sektor ekonomije (ruralni i urbani). Do reforme 1980. godine, ljudi su smeli da žive samo u svom hukou, bez mogućnosti selidbe, a tek 1990. godine ovaj sistem postaje opušteniji. lako sistem postaje fleksibilniji, a narod može da se zaposli u drugom hukou, njihovo zdrastveno osiguranje, podela zemlje, socijalna zaštita i obrazovanje je još uvek uslovljeno hukou-om (Li, Loyalka, Rozelle, \& Wu, 2017).

Od $64 \%$ ljudi koji žive u ruralnom hukou, $76 \%$ je $\mathrm{u}$ radnom odnosu, ali nakon reformi, ne rade svi u ruralnom hukou, ukoliko tamo žive. Iz ruralnog hukou-a 2014. godine, 31\% radnika je migriralno u gradove, dok od toga, $57 \%$ radi u industriji, a $43 \%$ u uslužnom sektoru (Annual Monitoring Survey on Rural Workers 2014). Socijalna zaštita ostaje problem, s obzirom da je populacija $u$ ruralnom hukou veća i siromašnija, a proces formiranja ovih programa počinje kasnije. Stanovnici u ruralnim predelima polako dobijaju pristup socijalnim uslugama, obaveznom devetogodišnjem obrazovanju, zdrastvenom osiguranju, socijalnoj zaštiti, kao i socijalnoj pomoći. Prema Annual Monitoring Survey on Rural Workers 2014, čak i ruralni stanovnici koji su migrirali u urbane sredine imaju poteškoće, jer često nisu pokriveni socijalnom zaštitom koju uživaju urbani stanovnici. Samo $16 \%$ ruralnih migranata je 2014. godine bilo pokriveno socijalnom zaštitom, $18 \%$ je imalo zdrastveno osiguranje, a $10 \%$ je imalo osiguranje za nezaposlene. Deca migranata nemaju osigurano mesto u državnim školama, tako da je kvalitet njihovog obrazovanja upitan.

Nedostatak podrške lokalne samouprave, pogotovo školstva otežava mogućnost da migranti podižu porodicu u gradovima, a ovo dalje osnažuje dualno radno tržište i dualni obrazovni sistem.

\subsection{Dualno tržište rada i dualni obrazovni sistem}

lako je došlo do velikih obrazovnih dostignuća, od 1978. godine celokupan broj obrazovane populacije iz ruralnih predela je ekstremno nizak. Prema proračunima baziranim na kalkulacijama autora Li i saradnika na osnovu Census 2010 i the Annual Monitoring Survey on Rural Workers 2014, 2015. godine $11,3 \%$ ljudi (starosti između 25 i 64 godina) iz ruralnog predela imaju samo srednjoškolsko obrazovanje.

U urbanom delu 44,1\% stanovnika ima srednjoškolsko obrazovanje. Manje od $40 \%$ dece iz ruralnog predela pohađa srednju školu u periodu 2007 - 2012. godine (Khor, et al., 2016).

Mladi koji žive u ruralnom hukou, nemaju pristup obrazovanju u urbanim sredinama, te je njihova šansa za daljim višim obrazovanjem na samom početku slaba, jer je obrazovanje u ruralnim predelima lošije. Ovo dalje ukazuje na problem da hukou sistem često određuje primanja stanovništva, te ne samo da deca imaju slabije šanse za obrazovanjem u urbanim mestima, već često nemaju dovoljno novca da sebi takvo obrazovanje priušte i usled toga biraju da ostanu u ruralnom hukou i nastave školovanje tamo.

Troškovi tercijalnog obrazovanja demotivišu decu iz siromašnih porodica i iz ruralnih predela da nastave dalje obrazovanje, jer im je ceo postupak otežan (Heckman \& Yi, 2012).

Iz ovog ugla gledano, finansiranje tercijalnog obrazovanja od strane porodice nije uvek učinkovito. Investicije u ljudski kapital imaju velike pozitivne efekte na društvo, te očekivati da roditelji sami finansiraju obrazovanje dece stvara kontraproduktivne rezultate, jer produbljuje međugeneracijsko siromaštvo.

Slika 3 pokazuje diskrepancu u prihodima $u$ domaćinstvima iz ruralnih i urbanih predela, što dalje pokazuje da porodice iz ruralnih predela zarađuju mnogo manje nego porodice iz urbanih predela, te im je i školovanje manje pristupačno. Urbana domaćinstva su predstavljena svetlo plavim stubićima, a ruralna domaćinstva tamno plavim. 


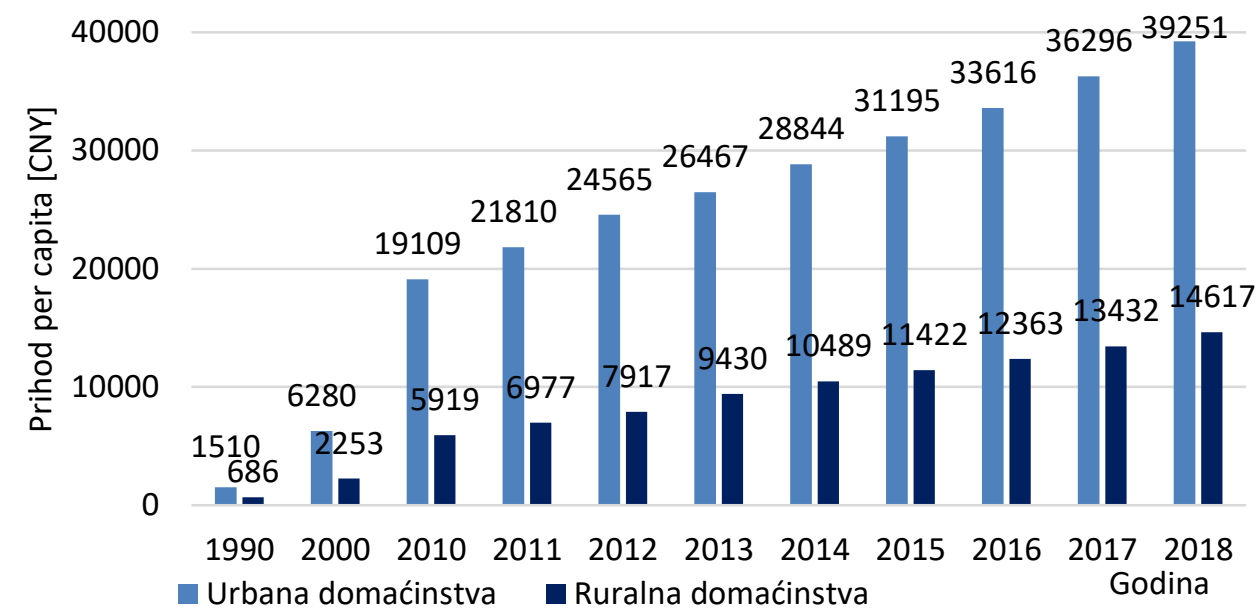

Slika 3. Prihod per capita u ruralnim i urbanim domaćinstvima u periodu 1990 - 2018. godine u yuan-u Izvor:(statista.com, 2019)

Neka od rešenja za ovaj problem su izgradnja škola u urbanim mestima, koje su namenjena za decu migranata, a između ostalog promovišu efikasnost i smanjuju problem nejednakosti. Krediti za školovanje na univerzitetima omogućavaju studentima da pozajme novac, a kredit otplate od buduće zarade, te ujedno pruža i veću priliku deci iz ruralnog hukou-a da nastave sa daljim obrazovanjem.

Ostaje izazov uskladiti deo obrazovanja, kvalitet radne snage, kao i održivi ekonomski rast. Izazov može biti manji ukoliko postoji ravnopravnost pristupa obrazovanju, smanjenje restrikcija mobilnosti i kreiranjem efikasnog tržišta koji bi formirao ljudski kapital (Heckman \& Yi, 2012).

Razlog za malu stopu pohađanja srednje škole su između ostalog visoki troškovi. Troškovi srednje škole u Kini iznose $\$ 160$ godišnje, što je $27 \%$ ruralnog prihoda per capita (Liu, i drugi, 2009), a školarine su uglavnom ogroman teret za studente iz ruralnih predela, koji nisu kvalifikovani za stipendiju. Osim ovog, problem je i rast plata za radnike sa osnovnim veštinama $(\mathrm{Li}, \mathrm{Lei}, \mathrm{Wu}, \&$ Xiong, 2012), te studenti neretko odustaju od obrazovanja da bi radili (Yi, et al., 2012). Problem sa decom iz ruralnih predela je takođe u razvitku kognitivnih i socijalnih veština, zbog nedostatka prisustva roditelja, koji odlaze da rade u urbanim sredinama. Istraživanje pokazuje da je teško zadržati profesore u ruralnim sredinama, koji su visoko obrazovani (Wei, 2016). Migratska deca iz ruralnog hukou sistema imaju poteškoće da budu upisana u kvalitetne državne škole u urbanim sredinama, te se odlučuju za migrantske škole u gradovima, koje su lošijeg kvaliteta. U ovim privatnim školama, profesori sistematski imaju niži nivo formalnog obrazovanja, čak i od nastavnika u državnim ruralnim školama (Wang \& Liu, 2016). Istraživanje takođe pokazuje da migrantska deca u migrantskim školama imaju gore rezultate od dece koja, napuštena od strane roditelja, ostaju u ruralnom hukou (Wang \& Liu, 2016).

Za razliku od ruralne, kineska urbana radna snaga je obrazovana. Prema podacima Census data 2010., 2015. godine je prosečan broj godina školovanja iznosio 10,7, a od ovog broja ljudi $44 \%$ ima završenu srednju školu, dok $21 \%$ fakultet. Prosečan broj godina koji se provede u školstvu u Kini iznosi 14 (slika 4).

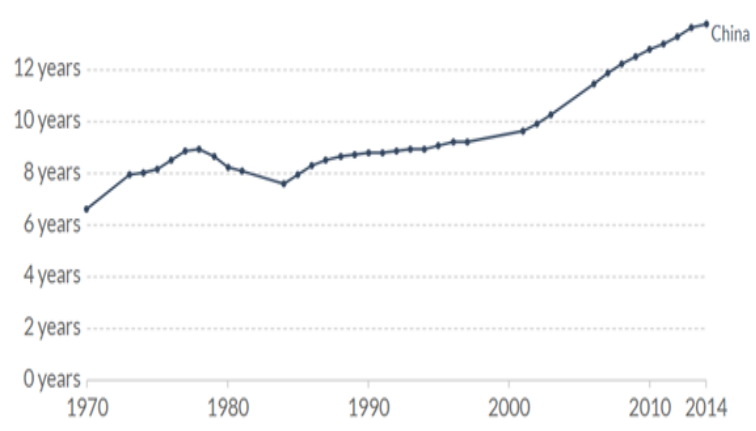

Slika 4. Očekivani životni vek obrazovanja od osnovne škole do fakulteta u Kini u periodu 1970 - 2014. godine

Izvor: (Svetska banka, 2014)

Upisna kvota u Kini je 1999. godine povećana za 43\%. Između 1999 - 2009. godine, godišnji rast stope upisa na fakultete iznosi $18,9 \%$. 
Stopa rasta za mlade između $18-22$ godine koji se upisuju na fakultet raste sa $10 \%$ (1998. godine) na $24 \%$ (2009. godine). Kako maturanti u najvećem slučaju ostaju u urbanim sredinama, ekspanzija univerziteta znači brzo poboljšanje ljudskog kapitala među urbanom radnom snagom, pogotovo među mladima. Ekspanzija fakulteta vodi do ulaganja u ljudski kapital koji može dovesti do ulaganja u fizički kapital $i$ prilagođavanja veština na osnovu tehnoloških promena (Acemoglu \& Robinson, 2012) (Hanushek \& Woessmann, 2010), što vodi do dalje produktivnosti i povrata investicija. Usled toga, gradovi i regioni gde dolazi do priliva ljudskog kapitala, kasnije doživljavaju povećanje produktivnosti kvalifikovane radne snage (Acemoglu \& Robinson, 2012). Potražnja za radnicima sa visokim kvalifikacijama nastaje usled stranih direktnih investicija i ekspanzijom trgovine 1990. godine. Pored ekspanzije stranih direktnih investija, dokazi i do priliva turista iz inostranstva u već razvijene delove u Kini (Blažević \& Chen, 2018).

\section{RAD I EKONOMSKI USPEH KINE NAKON 1978. GODINE}

Do 2014. godine, nakon više od tri decenije od reforme, dohodak Kine per capita iznosi $81 \%$ prosečnog nivoa globalnog odnosa. To dalje znači da dohodak Kine per capita raste $6,3 \%$ svake godine od 1980. godine, te dalje predstavlja $2 / 3$ kineskog godišnjeg rasta BDP-a, koji iznosi 9,7\% u periodu 1980 - 2014. godine. $\mathrm{Na}$ slici 5 je prikazan rast BDP u Kini u periodu 1961 - 2017. godine.

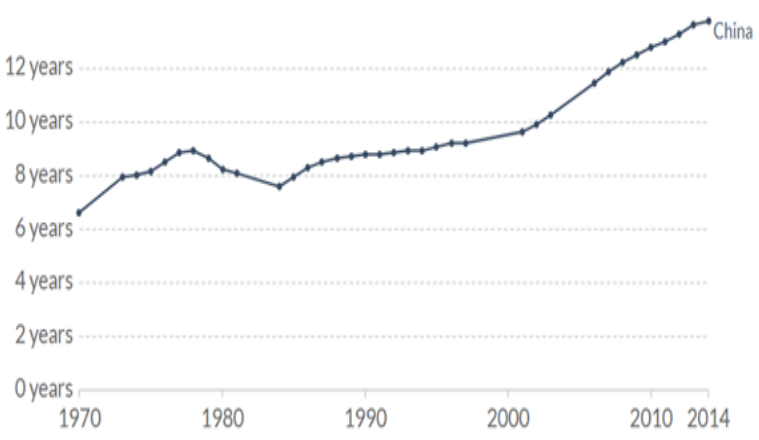

Slika 5. Godišnji rast BDP-a u Kini u periodu 1961 - 2017. godine

Izvor: (Svetska banka, 2018)

Godine školovanja za mlade starosti do 25 godina raste sa $4,0 \%$ na $8,8 \%$. Na osnovu linije regresije, možemo videti da je rast ljudskog kapitala povezan sa $3,8 \%$ godišnjeg rasta tokom 34 godine, što je $40 \%$ ukupnog rasta Kine. $U$ periodu 1980 - 2004. godine, Kineski dohodak per capita raste sa $\$ 599$ na $\$ 13,206$. Visok nivo obrazovanja je povezan sa $40 \%$ rasta per capita (Li, Loyalka, Rozelle, \& Wu, 2017).

Slika 6 pokazuje da ulaganje u obrazovanje pozitivno utiče na ekonomski rast. Na datoj slici se vidi da do 2007. godine ekonomski rast prati sve duže trajanje školovanja, međutim nakon 2007. godine rast BDP per capita polako opada, iako i dalje zadržava pozitivni trend, dok godine provedene u školstvu nastavljaju da rastu. Plava linija na grafikonu predstavlja rast BDP NR Kine, narandžasta linija predstavlja dužinu trajanja obrazovanja, dok isprekidana linija predstavlja rast BDP per capita. Treba imati u vidu da obrazovanje nije jedini faktor koji utiče na ekonomski razvoj, odnosno mora se uzeti u obzir da na pad BDP-a per capita mogu uticati i ostale okolnosti, kao što je npr. globalna ekonomska kriza.

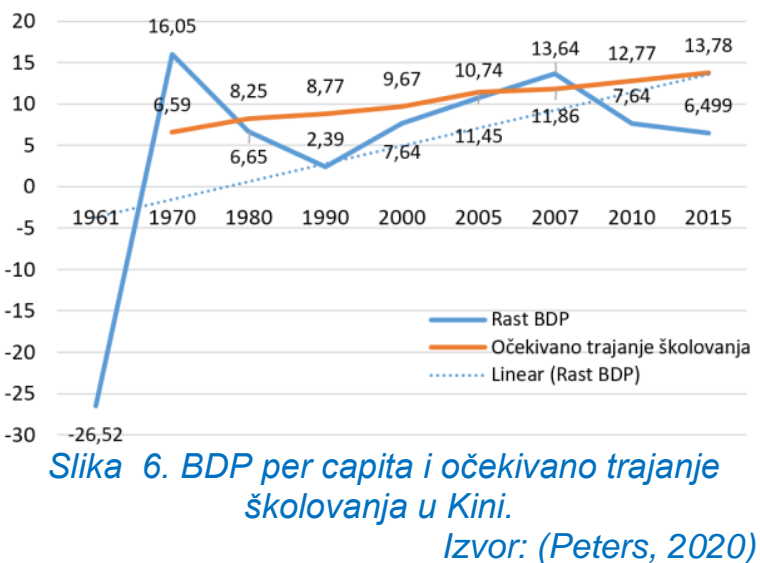

Nakon 1980. godine, radna produktivnost u Kini naglo raste, što uslovljava poboljšanje u ljudskom kapitalu i relokaciji radne snage u produktivnije sektore ekonomije (Li, Loyalka, Rozelle, \& Wu, 2017). Radna poduktivnost takođe raste usled promena u ekonomiji, tokom kojih dolazi do okreta od poljoprivrede na industriju i uslužne sektore, kao na primer ruralni turizam (Blažević, Peters, \& Chen, Developing rural tourism in minority ethnic villages: Zlot and Xiaocang She Ethnic township, 2018) U periodu 1978 - 2014., udeo radnika u poljoprivredi opada sa $71 \%$ na $30 \%$, a u uslužnom sektoru udeo raste sa $12 \%$ na $40 \%$. (Chinese Statistical Yearbook). U Kini je 12,6 miliona poslova automatizovano ili prebačeno u inostranstvo 2014. godine. Kina je na putu usvajanja novih tehnologija, za koje je 
neophodno prikupiti nove veštine, a ekonomija se bazira na znanju (knowledge-based economy). $\mathrm{Na}$ osnovu podataka Ministarstva obrazovanja u Kini, \$685 milijardi je 2018. godine uloženo u obrazovanje. Ulaganje u sektor za razvoj i istraživanje takođe raste, što pokazuje slika 7 .

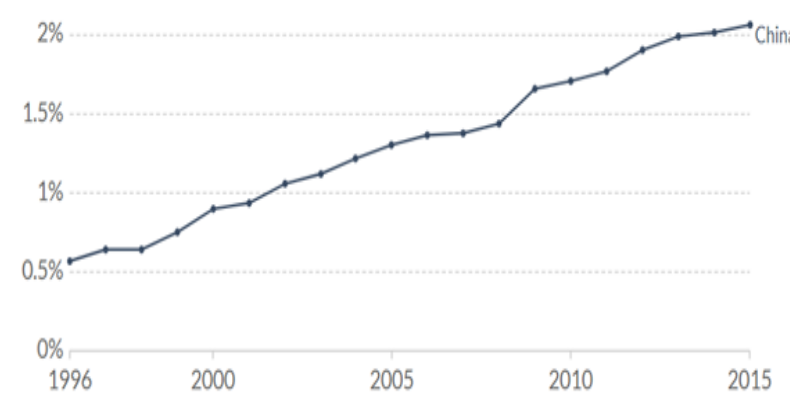

Slika 7. Ulaganje u istraživanje i razvoj u periodu 1996 - 2017. godine u Kini

Izvor: (Svetska banka, 2018)

Ukoliko Kina nastavi sa poboljšanjima na polju investicija u fizički kapital, tehnologiju i institucije koje podržavaju tržište, a povezane su sa rastom ljudskog kapitala, očekuje se godišnji porast za 2,3\% BDP u sledećih 20 godina. Po ovom scenariju, Kina bi dostigla nivo od $\$ 25,497$ per capita 2025. godine (Li, Loyalka, Rozelle, \& Wu, 2017).

Kina predviđa godišnji rast od $7 \%$, što znači da će dostici $\$ 54,682$ PPP per capita, što bi bio isti nivo prihoda kao što je imala SAD 2014. godine (\$54,629). U SAD-u je 2014. godine više od $44 \%$ radne snage imalo bar fakultetsku diplomu, a $89 \%$ završenu srednju školu. Ako se uzmu u obzir optimistična predviđanja za obrazovanje u Kini, nivo će ipak biti niži od SAD 2025. godine. Da bi se njihov cilj od $7 \%$ godišnjeg rasta ostvario, to bi značilo da Kina mora stvoriti još jaču vezu između ljudskog kapitala i dohotka per capita (Li, Loyalka, Rozelle, \& Wu, 2017).

\section{ZAKLJUČAK}

Cilj ovog rada je da utvrdi da li obrazovanje i investiranje u obrazovanje pozitivno utiče na ekonomski razvoj. Rad je koren svake ekonomije, a održivi razvoj podrazumeva da je ekonomija prosperativna, socijalno inkluzivna i ekološki održiva.

Kroz rad se osvrćemo na povezanost ekonomije i promena, kao i ekonomije i obrazovanja na primeru NR Kine. Moderna ekonomija je velikim delom definisana kroz tehnologiju što ostavlja prostor za poslove koji zahtevaju visoku kompetenciju i obrazovanje. Školstvo mora iznedriti sposobne studente koji će obavljati posao kvalitetno i biti pokretač ekonomije. Reforme u obrazovanju ne samo da su neophodne, već moraju biti dostupne svima, bez obzira na pol, rasu, etničko poreklo, religiju ili uzrast.

Empirijski podaci koji ukazuju na rast domaćeg bruto proizvoda, sa paralelom prisutnosti obrazovanja u Kini svedoče o vezi koju školstvo ima na ekonomski razvoj, ali je bitno naglasiti da obrazovanje nije jedini faktor koji utiče na ekonomiju. Ekonomski razvoj diktira reforme obrazovanja, ali i kvalitet obrazovanja diktira razvoj ekonomije, jer bez adekvatne radne snage zemlja ne može da se osloni na svoje ljude i njihove kompetencije, već je prinuđena da se oslanja na inovacije iz drugih zemalja. Ovim je potvrđeno da je obrazovanje od značaja za ekonomski rast.

Jedan od osnovnih ciljeva Made in China 2025 je između ostalog bolje upravljanje resursima pri raspodeli urbanim i ruralnim predelima, što bi značilo i bolju inkluziju ruralnog hukoa. Kina aktivno radi na svojim ciljevima, uslovljavajući globalne promene. Velika dela nose velike odgovornosti, te je neophodno da Kina nastavi sa transparentnošću, dostavljajući podatke o svojim investicijama, kako u unutrašnjosti zemlje, tako i međunarodno. Još uvek ima vrlo malo podataka o uslovima u ruralnim predelima, u cilju stvaranja prave slike o situaciji nejednakosti u Kini, kao i diskrepanci između ruralnih i urbanih predela, Kina mora biti spremna da govori o investicijama koje ulaže u ruralne predele, kao i na koji način podržava mlade da se lakše školuju i kasnije nađu posao u formalnoj ekonomiji.

\section{CITIRANA DELA}

Acemoglu, D., \& Robinson, J. (2012). Why Nations Fail: The Origins of Power, Prosperity, and Poverty. New York City: Crown Business. 
Becker, G., Ye, K., \& Yi, J. (2012). Rapidly growing human capital investment in China. Chicago: Unpublished manuscript.

Blažević, M., \& Chen, G. (2018). Image of Fujian Province as a Tourist Destination - A Foreigner's Perspective. Facta Universitatis Series Economics and Organization, 257-270.

Blažević, M., Peters, K., \& Chen, G. (2018). Developing rural tourism in minority ethnic villages: Zlot and Xiaocang She Ethnic township. Menadžment U Hotelijerstvu i Turizmu, 71-78.

Constant, A., Tien, B., Zimmermann, K. F., \& Meng, J. (2013). China's Latent Human Capital Investment: achieving milestones and competing for the top. Journal of Contemporary China, 109-130.

Feng, D. (2006). China's Recent Curriculum Reform: Progress and Problems. Planning and Changing, 131-144.

Guo, L. (2012). New Curriculum Reform in China and its Impacton Teachers. Canadian and International Education /Education canadienne et internationale, 87-105.

Hanushek, E., \& Woessmann, L. (2010). Education and Economic Growth. International, 2, 245-252.

Heckman, J., \& Yi, J. (2012). Human Capital, Economic Growth, and Inequality. NBER Working Paper, $1-10$.

Kang, O. (2004). Higher Education Reform in China Today. London: Policy Futures in Education.

Khor, N., Pang, L., Liu, C., Chang, F., Mo, D., Loyalka, P., \& Rozelle, S. (2016). China's Looming Human Capital Crisis: Upper Secondary Educational Attainment Rates and the Middle-income Trap. The China Quarterly, 1-22.

Li, H., Lei, L., Wu, B., \& Xiong, Y. (2012). The End of Cheap Chinese Labor. Journal of Economic Perspectives, 57-74.

Li, H., Loyalka, P., Rozelle, S., \& Wu, B. (2017). Human Capital and China's Future Growth. The Journal of Economic Perspectives, 25-47.

Liang, Y., Liu, Z., \& Li, H. (2016). Identifying Human Capital Externality: Evidence from China. JMSE, 75-93.

Liu, C., Zhang, L., Luo, R., Rozelle, S., Sharbono, B., \& Shi, Y. (2009). Development challenges, tuition barriers, and high school education in China. Asia Pacific Journal of Education, 503-520.

Marshall, T. (2015). Prisoners of Geography. New York City: Simon \& Schuster.

Otafiire, E., Lin, W., \& Blažević, M. (2019). The travel motives of outbound Chinese tourists. Turističko Poslovanje, 51-59.

Peters, K. (2020). Značaj investicija u obrazovanje za ekonomski razvoj Kine. Beograd: Univerzitet Singidunum.

Stamatović, M., \& Ercegović, M. (2020). Ljudski resursi- edukacija, informacione tehnologije, menadžment. FBIM Transactions, 157-166.

Wang, F., \& Liu, Y. Y. (2016). Interpreting Chinese Hukou System from a Foucauldian Perspective. Urban Policy and Research, 1-15.

Wei, Y. (2016). Teacher Mobility in Rural China: Evidence from Northwest China. Michigan: Michigan State University.

Yi, H., Zhang, L., Luo, R., Shi, Y., Mo, D., Chen, X., . . Rozelle, S. (2012). Dropping out: Why are students leaving junior high in China's poor rural areas? International Journal of Educational Development, 555-563. 
Received for publication:

03.04.2021.

Revision received:

06.04.2021.

Accepted for publication:

10.04.2021.

Kako citirati ovaj rad? / How to cite this article?

Style - APA Sixth Edition:

Peters, K., \& Blažević, M. (2021, 04 15). Značaj investicija u obrazovanje za ekonomski razvoj NR Kine. (Z. Čekerevac, Ur.) FBIM Transactions, 9(1), 88-97. doi:10.12709/fbim.09.09.01.09

Style - Chicago Sixteenth Edition:

Peters, Katarina, i Marko Blažević. 2021. „Značaj investicija u obrazovanje za ekonomski razvoj NR Kine." Urednik Zoran Čekerevac. FBIM Transactions (MESTE) 9 (1): 88-97. doi:10.12709/fbim.09.09.01.09.

Style - GOST Name Sort:

Peters Katarina i Blažević Marko Značaj investicija u obrazovanje za ekonomski razvoj NR Kine [Časopis] // FBIM Transactions / ur. Čekerevac Zoran. - Beograd : MESTE, 1504 2021. - 1 : T. 9. - str. 88-97.

Style - Harvard Anglia:

Peters, K. \& Blažević, M., 2021. Značaj investicija u obrazovanje za ekonomski razvoj NR Kine. FBIM Transactions, 15 04, 9(1), pp. 88-97.

Style - ISO 690 Numerical Reference:

Značaj investicija u obrazovanje za ekonomski razvoj NR Kine. Peters, Katarina i Blažević, Marko. [ur.] Zoran Čekerevac. 1, Beograd : MESTE, 1504 2021, FBIM Transactions, T. 9, str. 88-97 